\title{
PREGNANCY-BLOCK IN FEMALE MICE PLACED IN BOXES SOILED BY MALES
}

\author{
A. S. PARKES AND H. M. BRUGE \\ Physiological Laboratory, Cambridge and National Institute for Medical Research, \\ London, N.W.7
}

(Received 6th March 1962)

\begin{abstract}
Summary. Newly mated female mice were placed singly for periods of up to 3 days in boxes recently vacated by five males of a different strain (alien males). When the soiled boxes were renewed twice daily, the females showed pregnancy-block to the same extent as when placed in the proximity of alien males for similar periods. When the soiled boxes were renewed once daily, the incidence of pregnancy-block was much reduced. An equal amount of disturbance, caused by similarly transferring the females to clean cages, did not affect the incidence of pregnancy.

These results support previous work in indicating that the smell of the alien male is the operative factor in pregnancy-block, and further suggest that the odorous substances involved are highly evanescent.
\end{abstract}

\section{INTRODUCTION}

Ovo-implantation is blocked in about $80 \%$ of newly-mated female mice exposed for 3 days to alien males (i.e. of a strain different from that of the stud male) (Bruce, 1959). Contact between the females and the alien males is not necessary to produce the reaction (Bruce, 1960a) and anosmic females do not show it (Bruce \& Parrott, 1960). It thus seemed very probable that the smell of the alien males is the operative factor.

Further experiments were therefore undertaken in which newly mated females were placed in boxes recently vacated by alien males, a technique similar to that employed by Whitten (1956) in his work on the synchronization of oestrus in grouped females newly exposed to males. At first, as exposure of the females in soiled boxes did not produce pregnancy-block, the stimulus was intensified by housing the animals in tall glass jars, with reduced ventilation, on cloth bedding highly retentive of animal smells, and renewing the soiled container twice daily for the 3-day-exposure period (Days 1 to 4 after mating). In this experimental situation, twenty-eight out of thirty-three newly mated females failed to become either pregnant or pseudopregnant and returned to oestrus within 7 days (Bruce, 1960b). Under these conditions, therefore, confinement in soiled jars was as effective as the proximity of males in causing pregnancy-block. Further analysis of the necessary conditions was then undertaken. 


\section{MATERIALS AND TECHNIQUE}

As in previous experiments, albino mice of the Parkes stock were allowed to mate with stud males of the same strain. On the day following the finding of the vaginal plug they were put singly into containers vacated immediately before by five CBA or G strain males. The females remained in the test situation for $12 \mathrm{hr}, 1$ day, 2 days or 3 days, the boxes, previously soiled by males for 12 or $24 \mathrm{hr}$, being renewed once or twice daily. In some experiments, the males were transferred from the soiled box to a clean box, and a female followed the same five males through a succession of boxes; in others, the female and the five males were alternated between two boxes, so that a soiled box was re-soiled, after the removal of the female, in preparation for her return.

Standard mouse boxes, 15 in. $\times 6$ in. $\times 4$ in. were used, the lid being solid except at the end holding the food basket and water bottle. In such boxes, the ventilation is much better than in the glass jars, and is known to be entirely adequate for five mice. Cloth bedding, in the form of a double layer of cotton drill, without sawdust, was used in all experiments, except where mentioned. The material was washed each time on removal from a box and used again later.

As in previous experiments, vaginal smears were taken from the females for 7 days and a return of vaginal cornification within this time was taken to indicate a blocked pregnancy. The females were observed up to 21 days after mating, and those in which pregnancy was not blocked were classified as 'having litters' or 'presumed pseudopregnant'.

In simultaneous control experiments, newly mated mice transferred to clean boxes once or twice daily for $12 \mathrm{hr}$ to 3 days showed no ill effects; only six out of seventy-four $(8 \%)$ returned to oestrus within 7 days. This figure for spontaneous failure of pregnancy and pseudopregnancy is similar to that given by Bruce (1959).

\section{RESULTS}

\section{EFFECTIVENESS OF SOILED BOXES}

Exposure of the females in soiled boxes changed twice daily for 3 days gave results very similar to those obtained with the glass jars, thirty-five out of forty-two $(83 \%)$ of the females returned to oestrus within 7 days. When the period of exposure in soiled cages was reduced to 2 days, the incidence of pregnancy-block decreased slightly but significantly. A second experiment in which the females and the males were alternated between two boxes, was carried out some 5 months later (January to February, 1961) with the assistance of a different technician unaware of the detailed results of the first experiment, and gave almost identical results (Table 1).

\section{NEGESSARY PERIOD OF EXPOSURE}

Experiments on the necessary duration of exposure in soiled boxes renewed twice daily were continued by reducing the time to 1 day and then to $12 \mathrm{hr}$. The results (Table 2), taken together with those recorded above, are very 
similar to those obtained by exposure of females for different periods to the proximity of males (Bruce, 1961), and warrant the conclusion that the males leave the operative substances behind them in the soiled box.

TABLE 1

PREGNANCY-BLOCK IN NEWLY MATED FEMALE MICE PLACED IN BOXES SOILED BY ALIEN MALES AND RENEWED TWICE DAILY

\begin{tabular}{l|c|c|c|c}
\hline & \multicolumn{3}{|c}{ Proportion and \% of females } \\
\cline { 2 - 4 } $\begin{array}{c}\text { Date of experiment and } \\
\text { nature of exchange }\end{array}$ & $\begin{array}{c}\text { Duration } \\
\text { of exposure } \\
\text { (days) }\end{array}$ & $\begin{array}{c}\text { Having blocked } \\
\text { pregnancies }\end{array}$ & $\begin{array}{c}\text { Having } \\
\text { litters }\end{array}$ & $\begin{array}{c}\text { Presumed } \\
\text { pseudopregnant }\end{array}$ \\
\hline $\begin{array}{c}\text { August to } \\
\begin{array}{c}\text { September 1960 } \\
\text { (Males transferred to } \\
\text { a clean box at each } \\
\text { exchange) }\end{array}\end{array}$ & 2 & $\begin{array}{c}50 / 68 \\
73 \cdot 5 \%\end{array}$ & $14 / 68$ & $4 / 68$ \\
\hline $\begin{array}{c}\text { January to } \\
\text { February 1961 } \\
\text { (Males and females } \\
\text { exchanged soiled } \\
\text { boxes) }\end{array}$ & 3 & $\begin{array}{c}35 / 42 \\
83 \cdot 3 \%\end{array}$ & $4 / 42$ & $3 / 42$ \\
\hline
\end{tabular}

TABLE 2

DURATION OF EXPOSURE IN BOXES SOILED BY ALIEN MALES AND THE INGIDENCE OF PREGNANCY BLOCK

\begin{tabular}{l|c|c|c|c}
\hline \multirow{2}{*}{$\begin{array}{c}\text { Length of } \\
\text { exposure }\end{array}$} & \multicolumn{2}{|c|}{$\begin{array}{c}\text { Boxes } \\
\text { changed a.m. and p.m. }\end{array}$} & \multicolumn{2}{|c}{$\begin{array}{c}\text { Boxes } \\
\text { changed a.m. only }\end{array}$} \\
\cline { 2 - 4 } & Proportion & $\%$ & Proportion & $\%$ \\
\hline 3 days & $86 / 103$ & 84 & $21 / 38$ & 55 \\
2 days & $89 / 121$ & 74 & $16 / 32$ & 50 \\
1 day & $27 / 46$ & 59 & $15 / 40$ & 38 \\
12 hr & - & - & $13 / 40$ & 33 \\
\hline
\end{tabular}

Exposure of the females in soiled boxes renewed only once daily, though not innocuous, is far less effective in causing pregnancy-block than exposure in boxes changed twice daily, or exposure to the proximity of males (Table 2 and Text-fig. 1).

\section{NATURE OF THE BEDDING}

The question of whether a woody smell might interfere with the effect of the smell of the soiled box was investigated by adding elastin to the cloth bedding. In a 2-day experiment, in which the soiled boxes were renewed twice daily, twenty out of twenty-seven (74\%) females returned to oestrus within 7 days, a result indistinguishable from that obtained with the cloth bedding alone. Sawdust bedding alone may have been slightly less effective, thirty-one out of forty-five $(68 \%)$ of females showing blocked pregnancy. 


\section{INEFFEGTIVENESS OF DISTURBANCE ALONE}

These experiments demanded considerable handling and territory displacement of the female during the first 3 days of pregnancy. Before a final interpretation of the results could be made, it was thought desirable to examine in further detail the possible effects of such disturbance uncomplicated by residual emanations from other mice. In a last experiment, therefore, the newly-mated female was transferred to a series of clean boxes with sawdust bedding, or returned to a box previously soiled only by herself. At the end of the period of experimental disturbance, she was returned, as the females exposed to male mice aromas had been, to the same box which she had occupied on her separation from the stud male. The results are shown in Table 3.

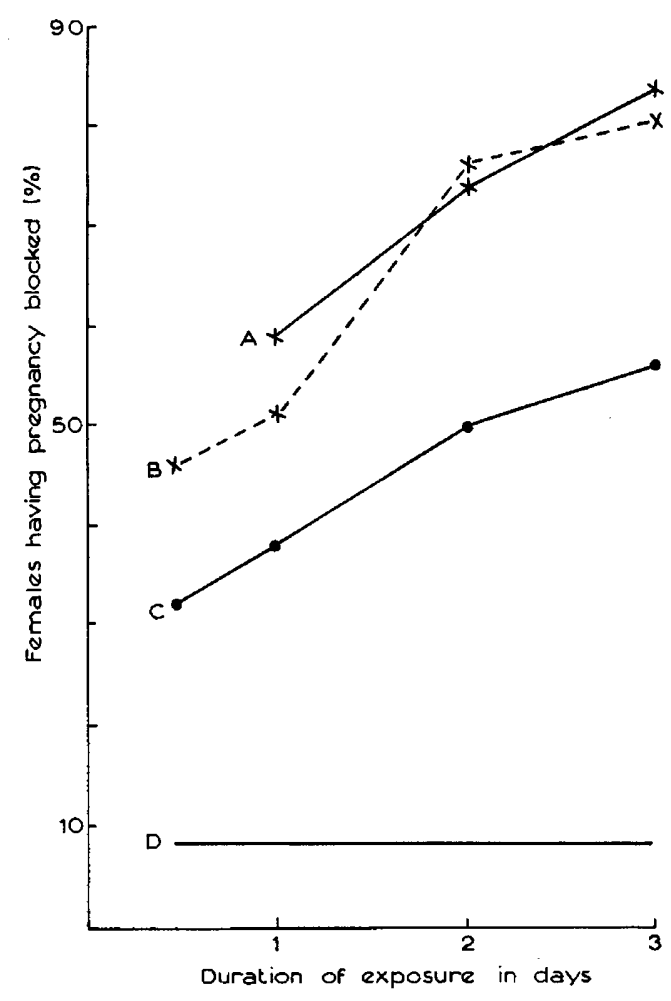

TEXT-FIG. 1. Incidence of pregnancy-block in females.

$\mathrm{A}=$ Placed in boxes soiled by alien males and renewed twice daily for 1 to 3 days.

$\mathrm{B}=$ Exposed to the proximity of alien males for $12 \mathrm{hr}$ to 3 days.

$\mathrm{C}=$ Placed for $12 \mathrm{hr}$ to 3 days in boxes soiled by alien males. Boxes renewed once daily.

$\mathrm{D}=$ Disturbed to a similar extent by transference to clean boxes. Overall average.

Without the intervention of male mice, the experimental procedures did not affect either pregnancy or pseudopregnancy, neither did the substitution of cloth bedding for sawdust. Indeed, among the whole series of 152 females so disturbed, only twelve returned to oestrus within a week of mating, a figure remarkably close to that recorded earlier for spontaneous failure in this stock of mice (Bruce, 1959). Likewise, among undisturbed females examined at the 
same time, two out of forty returned to oestrus. This again accords with previous results and indicates that little change in general reproductive vigour had occurred in the colony during the past 3 years. Only eight females out of nearly 200 in the experiment became pseudopregnant, pregnancy being normal in the remainder (170 out of 192).

TABLE 3

DISTURBANCE OF THE RECENTLY-MATED FEMALE AND FAILURE OF PREGNANCY AS SHOWN BY THE RETURN OF OESTRUS

\begin{tabular}{c|c|c}
\hline $\begin{array}{c}\text { Period covered } \\
\text { by } \\
\text { disturbance }\end{array}$ & $\begin{array}{c}\text { Boxes } \\
\text { changed a.m. and p.m. }\end{array}$ & $\begin{array}{c}\text { Boxes } \\
\text { changed a.m. only }\end{array}$ \\
\hline 3 days & $1 / 23$ & $0 / 24$ \\
2 days & $5 / 24$ & $2 / 19$ \\
1 day & $2 / 16$ & $2 / 22$ \\
$12 \mathrm{hr}$ & - & $0 / 24$ \\
\hline
\end{tabular}

\section{DISGUSSION}

The results recorded above make it very probable that the success with the glass jars described earlier was due not to reduced ventilation or to the nature of the bedding, but to the twice-daily renewal of the soiled container. Moreover, the results suggest strongly that the soiled box has lost its potency completely in $12 \mathrm{hr}$, because (a) there is no augmentation of effect by returning the males to a soiled box from which the females have been removed as compared with allowing them to soil a clean one (Table 1$) ;(b)$ once-daily renewal of the soiled box is markedly inferior to twice-daily (Table 2). Evidently, the operative substances are evanescent, highly volatile or highly labile, probably both. The experiments described do not in themselves entirely preclude the possibility that the active substances are taken in by the females by ingestion or inhalation, but equally they provide no reason to modify the previous conclusion that olfaction is the essential mechanism. Certainly the experiments described dispose of any idea that vision or audition is involved.

The data on the necessary duration of the stimulus confirm the indications from experiments based on proximity of the alien males. At present, we have no information about the relation, if any, between the intensity and the necessary duration of the olfactory stimulus. With the intensity of stimulus provided by the residual emanations of five alien males, exposure for $24 \mathrm{hr}$ is necessary to give unequivocal results, but it might be that a much shorter period would be adequate if the stimulus could be further intensified. This is an important point, because of its bearing on the nature of the neurohumoral mechanism, but the answer must await further experimentation, possibly even the concentration of the odorous substances involved into an effective preparation. At present, it seems that as an exteroceptive factor the olfactory stimulus for pregnancy-block (almost certainly a neuro-adenohypophysial reaction) acts more rapidly than does, say, light in affecting the reproductive cycle (also a neuro-adenohypophysial reaction), but much more slowly than the sensory stimuli evoking 
sexual behaviour (a neural reaction) or milk let-down (a neuro-neurohypophysial reaction). It may perhaps be similar in speed of action to the suckling stimulus required to maintain mammalian lactation (another neuro-adenohypophysial reaction).

The source of the operative odours produced by male mice is at present quite unknown, but preparations of the urine and faeces of alien males collected in metabolism cages have so far failed to reproduce the effect of the soiled cage. Possibly experimental conditions have been unsuitable, or the operative odorous substances have some other origin in the males. It is one of the oddities of this subject that while almost everyone knows the smell of mice, it seems that no one knows its source or nature.

\section{REFERENCES}

Bruce, H. M. (1959) An exteroceptive block to pregnancy in the mouse. Nature, Lond. 184, 105.

BRUCE, H. M. (1960a) A block to pregnancy in the mouse caused by the proximity of strange males. 7. Reprod. Fertil. 1, 96.

BRUCE, H. M. (1960b) Further observations on pregnancy block in mice caused by the proximity of strange males. F. Reprod. Fertil. $1,311$.

BRUCE, H. M. (1961) Time relations in the pregnancy block induced in mice by strange males. $\mathcal{F}$. Reprod. Fertil. 2, 138.

Bruce, H. M. \& PARrot', D. M. V. (1960) Role of olfactory sense in pregnancy block by strange males. Science, 131, 1526.

Whitren, W. K. (1956) Modification of the oestrous cycle of the mouse by external stimuli associated with the male. F. Endocrin. 13, 399. 